\title{
HEC-HMS Model for Urban Flood Analysis in Belik River, Yogyakarta, Indonesia
}

\author{
Slamet Suprayogi ${ }^{1,{ }^{*}}$, Rifai $^{1}$, and Reviana Latifah ${ }^{1}$ \\ ${ }^{1}$ Department of Environmental Geography, Faculty of Geography, Universitas Gadjah Mada, Sekip Utara, Bulaksumur, Yogyakarta 55281, \\ Indonesia \\ ${ }^{*}$ Corresponding author: ssuprayogi@ugm.ac.id
}

\section{KEYWORDS \\ Flood \\ HEC-HMS \\ Indonesia \\ Urban}

SUBMITTED 19 September 2020 REVISED 11 March 2021

ACCEPTED 20 March 2021

\begin{abstract}
The rapid development of Yogyakarta has made city development increase. This construction continues to expand the reach of impervious surfaces. As a result, surface runoff and maximum discharge have increased, overflowing up to urban drainage. This study aimed to analyze the maximum discharge of the watershed based on design storms with 2, 5, 10, and 25-year return periods, used for flood control considerations. The urban flood was modelled using HEC-HMS. The results showed that the contribution of discharge flow in each segment is influenced by the dominance of land use, in which the segment dominated by dense settlements has a high contribution to the maximum discharge. The flow contribution is due to the high curve number value, which corresponds to the high surface runoff. The peak discharge of watersheds with return periods of $2,5,10$, and 25 years are $8 \mathrm{~m}^{3} / \mathrm{s}, 20.1 \mathrm{~m}^{3} / \mathrm{s}$, $29.9 \mathrm{~m}^{3} / \mathrm{s}$, and $44.1 \mathrm{~m}^{3} / \mathrm{s}$, respectively.
\end{abstract}

(c) The Author(s) 2021. This article is distributed under a Creative Commons Attribution-ShareAlike 4.0 International license.

\section{INTRODUCTION}

The concept of space utilization in Indonesia is regulated by the Regional Spatial Plan (Rencana Tata Ruang Wilayah), which factors in Floor Area Ratio (FAR). FAR draws on hydrological assumptions that emphasize water conservation to achieve a quantitative balance in rainfall partitioning into infiltrated water and runoff. In developing regions, the prominent obstacle to such an objective is uncontrolled building permits (Izin Mendirikan Bangunan), creating discordance between spatial developments and water conservation principles.

The rapid development of Yogyakarta, a city in Indonesia, has led to changes in space utilization. According to Prihatin (2015), its tourism, trade, and service industries have multiplied intensively, as evident from the development of transportation infrastructure and increased space utilization from single to multiple occupations. Yogyakarta holds the titles of Student City, Tourism City, and Cultural City, which implies a potentially soaring number of people moving into it. As such, there is an increasingly high demand for land to accommodate housing, investment, warehousing businesses, industrial estates, and tourism. Development in the city can continuously widen the extent of impervious surfaces.

Built-up land decreases the ability of a watershed to absorb, retain, and store rainwater, thus increasing surface runoff and maximum discharge (Maria and Lestiana 2014; Nainggolan et al. 2015; Marko and Zulkarnain 2018; Suprayogi et al. 2020). An impermeable soil surface prevents water from infiltrating into the soil. This means that rainfall is mostly partitioned into runoff and can cause rainwater to overflow urban drainage channels. Flooding in urban areas is also caused by the lack of retention and drainage capacity available in the city (Jamali et al. 2018). Some of the areas that were inundated by the overflow of Belik River were around Colombo Street and Kampung Klitren (Suprayogi et al. 2019). Based on local news, events that were quite detrimental were in 2012, 2018, and early 2020. Water overflowed to residents' houses because the embankment was broken due to not being able to withstand the swift river water.

Flood studies mostly use HEC-HMS (Hydraulic Engineering Center-Hydrologic Modeling System) models for various hydrological simulations in different watersheds. HEC-HMS was created by the US Army Corps of Engineers (USACE) to simulate precipitation-runoff processes. HECHMS runs programs for studying watershed physical descriptions, meteorology descriptions, and hydrologic simulations (USACE 2018). According to Bajwa (2002), there are four main contents of HEC-HMS. First, it provides an analytical model for runoff calculation. Second, the components of the hydrological system are graphically represented and illustrated with interactive features. Third, it is a system that can store and manage long time-series data. And fourth, it provides a means of presenting and reporting the model output.

The HEC-HMS model is used to determine the flood discharge of a watershed, so the input data used is simpler than the HEC-RAS model because it does not require river geometric data. Abushandi and Merkel (2013) applied HECHMS to reproduce a flood event in an arid catchment, while Halwatura and Najim (2013) used it to simulate runoff in a tropical catchment. Building a HEC-HMS model, Majidi and Shahedi (2012) could synthesize the rainfall-runoff process in a watershed in southern Iran, and Yusop et al. (2007) predicted runoff in an oil palm catchment. In a watershed, periodic floods can occur as streamflow that exceeds channel 
capacity. The Belik Watershed is located in an urban area and is mainly used for residential purposes. Extreme rain events often lead to overflows onto the banks of Belik River. This research is important as one of the inputs in the form of the maximum discharge (flood) of the watershed, so that it can be used to evaluate the capacity of the water channel. This research set out to analyze the maximum discharge of the watershed based on design storms with $2,5,10$, and 25 -year return periods. The analysis results provide consideration for flood control in urban areas.

\section{METHODS}

\subsection{Study area}

The HEC-HMS model was applied to the maximum discharge analysis of the Belik Watershed, part of an urban area of Yogyakarta. This watershed covers an area of 8.31 $\mathrm{km}^{2}$, with a river length of $6.93 \mathrm{~km}$. The research began with partitioning the Belik Watershed into three segments based on estimated flood-prone sites; this segmentation is presented in Figure 1. Segment 1 has an area of $2.98 \mathrm{~km}^{2}$ with a river length of $2.23 \mathrm{~km}$, while segment 2 is $1.67 \mathrm{~km}^{2}$ in extent and has a river length of $1.11 \mathrm{~km}$. Segment 3 covers an area of $3.46 \mathrm{~km}^{2}$, and the river is $3.59 \mathrm{~km}$ in length.

\subsection{HEC-HMS model}

The HEC-HMS model applied to the Belik Watershed was comprised of four components, namely a basin model (describing the physical watershed and river network topology), a meteorological model (simulating precipitation

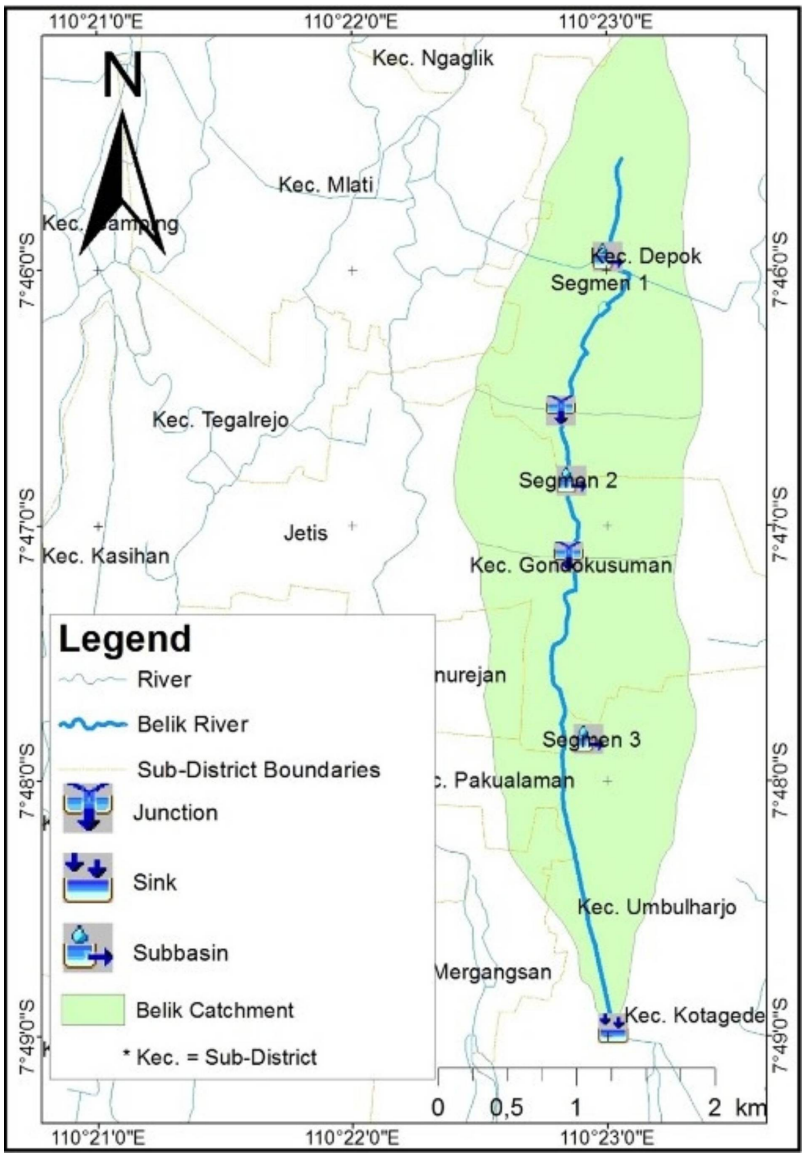

FIGURE 1. Segmentation of the Belik Watershed for maximum discharge analysis. data), a control specification (defining the time constraints of the model), and time-series data. A basin model contains the modeling components that describe canopy interception, surface storage, infiltration, surface runoff, baseflow, channel routing, and lakes (USACE 2018). The basin model was created in ArcGIS 10.4 using the HEC-GeoHMS 10.4 extension. The meteorological model was built using a specified hyetograph, where each segment was simulated and assigned with precipitation data. The control specification and time-series data were created with a one-minute interval. The components of the HEC-HMS model were built with the specifications listed in Table 1.

\subsection{Curve number (CN) determination}

The Belik Watershed is composed mostly of built-up land used for offices and residential areas. Due to this, there is increasingly less rainwater infiltrating the soil, and, thus, a larger portion of rainfall transforms into surface runoff. Details on land use and soil enable the estimation of curve numbers (CN), an input of the HEC-HMS model. The Soil Conservation Service-Curve Number (SCS-CN) was used in this study because it offers a relatively easy method of predicting the quantity of rainwater that changes into runoff. Its requirements are also straightforward: land use data and hydrologic soil conditions. The $\mathrm{CN}$ in hydrology is used to predict runoff potential (Castro and Maidment 2020). Here, the SCS-CN value refers to the TR-55 land use description, as summarized in Table 2.

\subsection{Maximum discharge analysis}

In the HEC-HMS model, the generation of a unit hydrograph requires time-series rainfall records, which in this case were peak storms potentially occurring at a given return period. These data were obtained from the design storm that had an equal duration to the time of concentration (Tc). Tc is the time required for rain falling on the farthest part of a watershed area to reach its outlet. Every segment has a storm duration that is different from the Tc. Total rainfall volume is the design storm assumed to have constant intensity ( $\mathrm{mm} /$ minute) during Tc. The design storm intensities, serving as the input to the simulation, are presented in Tables 3 and 4.

\section{RESULTS AND DISCUSSION}

HEC-HMS models are reliable for various hydrological simulations. Although they appear to be straightforward, they are nonetheless deemed to be accurate at predicting floods (Oleyiblo and Li 2010). Sarminingsih et al. (2019) agree that, based on their research in the Garang Watershed, HECHMS shows relatively good performance in modeling the rainfall-runoff process. Ud Din et al. (2018) add that the same level of performance even applies to rural watersheds.

TABLE 1. Components of the HEC-HMS model for the maximum discharge analysis of the Belik Watershed.

\begin{tabular}{lll}
\hline No. & Model & Method \\
\hline 1 & Precipitation & Specified Hyetograph \\
2 & Transformation & SCS's UH \\
3 & Runoff Volume & SCS-CN (TR-55) \\
4 & Baseflow & Not Calculated \\
5 & Routing & Lag \\
\hline
\end{tabular}


TABLE 2. SCS-CN values based on the TR-55 land use description (USDA-SCS 1986).

\begin{tabular}{|c|c|c|c|c|c|c|}
\hline \multirow[t]{3}{*}{ Land use description } & \multicolumn{6}{|c|}{ TR-55 land use description and curve numbers } \\
\hline & \multicolumn{2}{|l|}{ Land cover description } & \multicolumn{4}{|c|}{ CN for hydrologic soil group } \\
\hline & Cover type and hydrologic condition & $\%$ impervious areas & A & B & C & $\mathrm{D}$ \\
\hline Agricultural & Row crops - straight rows + crop residue cover - good condition & & 64 & 75 & 82 & 85 \\
\hline Commercial & Urban districts: commercial and business & 85 & 89 & 92 & 94 & 95 \\
\hline Forest & Woods - good condition & & 30 & 55 & 70 & 77 \\
\hline Grass/pasture & Pasture, grassland, or range - good condition & & 39 & 61 & 74 & 80 \\
\hline High-density residential & Residential districts by average lot size: $1 / 8$ acre or less & 65 & 77 & 85 & 90 & 92 \\
\hline Industrial & Urban district: industrial & 72 & 81 & 88 & 91 & 93 \\
\hline Low-density residential & Residential districts by average lot size: $1 / 2$ acre lot & 25 & 54 & 70 & 80 & 85 \\
\hline Open spaces & $\begin{array}{l}\text { Open space (e.g. lawns, parks, golf courses, and cemeteries, } \\
\text { etc.) - fair condition (grass cover } 50 \% \text { to } 70 \% \text { ) }\end{array}$ & & 49 & 69 & 79 & 84 \\
\hline Parking and paved spaces & $\begin{array}{l}\text { Impervious areas (e.g. paved parking lots, roofs, and driveways, } \\
\text { etc. excluding right-of-way) }\end{array}$ & 100 & 98 & 98 & 98 & 98 \\
\hline Residential $1 / 8$ acre & Residential districts by average lot size: $1 / 8$ acre or less & 65 & 77 & 85 & 90 & 92 \\
\hline Residential $1 / 4$ acre & Residential districts by average lot size: $1 / 4$ acre & 38 & 61 & 75 & 83 & 87 \\
\hline Residential $1 / 3$ acre & Residential districts by average lot size: $1 / 3$ acre & 30 & 57 & 72 & 81 & 86 \\
\hline Residential $1 / 2$ acre & Residential districts by average lot size: $1 / 2$ acre & 25 & 54 & 70 & 80 & 85 \\
\hline Residential 1 acre & Residential districts by average lot size: 1 acre & 20 & 51 & 68 & 79 & 84 \\
\hline Residential 2 acres & Residential districts by average lot size: 2 acre & 12 & 46 & 65 & 77 & 82 \\
\hline Water/wetlands & & 0 & 0 & 0 & 0 & 0 \\
\hline
\end{tabular}

Based on these accounts, the rainfall data inputted to the model in this study were derived from design storm calculations. The results of simulations with the HEC-HMS model can subsequently be incorporated into the management of the Belik Watershed.

Land use conditions in the Belik watershed in 2013 were dominated by settlements, covering an area of 204.42 ha (Suprayogi et al. 2019). Construction continues to this day, both repairing roads and other infrastructure, as well as construction of new buildings. The decrease in the surface layer of the soil that is replaced by paving, cast block, and asphalt, results in the water catchment area decreasing. The percentage of water discharged directly is greater than that which is absorbed into the soil. This condition can be seen from the CN value (USDA-SCS 1986), areas with population density, commercial, industrial, and asphalt/paved areas have a greater $\mathrm{CN}$ value. This means that the greater the $\mathrm{CN}$ value, the greater the direct runoff. The $\mathrm{CN}$ value of the watershed observed was calculated from the land use condition in 2019, as derived through remote sensing image interpretation. The Belik Watershed has a uniform hydrologic soil group, that is, Class A. After calculating the SCS-CN for the entire watershed (as mapped in Figure 2), the analysis continued with estimating the $\mathrm{CN}$ value of each segment. The results showed that segments 1,2 , and 3 had average CNs of $68.06,72.15$, and 71.22 , respectively.

TABLE 3. Design storms and times of concentration (Tc) of every segment of the Belik Watershed.

\begin{tabular}{llrrrr}
\hline \multirow{2}{*}{ Segment } & \multirow{2}{*}{ Tc (min) } & \multicolumn{4}{c}{ Return period $(\mathrm{mm})$} \\
\cline { 3 - 6 } & & 2-year & 5-year & 10-year & 25-year \\
\hline 1 & 41.29 & 38.25 & 54.26 & 64.49 & 77.39 \\
2 & 27.97 & 49.59 & 70.35 & 83.61 & 100.33 \\
3 & 67.91 & 27.45 & 38.94 & 46.29 & 55.54 \\
\hline
\end{tabular}

\subsection{Peak discharge with 2-year return period}

Based on the 2-year design storm, the calculated peak discharge at the outlet of the Belik Watershed was $8.0 \mathrm{~m}^{3} / \mathrm{s}$. Segments 1, 2, and 3 produced peak discharges of $0.4 \mathrm{~m}^{3} / \mathrm{s}$, $2.3 \mathrm{~m}^{3} / \mathrm{s}$, and $7.8 \mathrm{~m}^{3} / \mathrm{s}$, respectively. The flood hydrograph at the watershed outlet for the design storm with a 2-year return period is presented in Figure 3.

\subsection{Peak discharge with 5-year return period}

The 5-year design storm simulation resulted in an estimated peak discharge at the outlet of the Belik Watershed was $20.1 \mathrm{~m}^{3} / \mathrm{s}$. Segments 1,2 , and 3 accordingly yielded peak discharges of $2.9 \mathrm{~m}^{3} / \mathrm{s}, 8.4 \mathrm{~m}^{3} / \mathrm{s}$, and $18.4 \mathrm{~m}^{3} / \mathrm{s}$, respectively. The flood hydrograph of the Belik Watershed outlet based on the design storm with a 5-year return period is displayed in Figure 4.

\subsection{Peak discharge with 10-year return period}

Meanwhile, based on the 10-year design storm, the estimated peak discharge at the outlet of the Belik Watershed observed was $29.9 \mathrm{~m}^{3} / \mathrm{s}$. Segments 1, 2, and 3 yielded peak discharges of $5 \mathrm{~m}^{3} / \mathrm{s}, 13.7 \mathrm{~m}^{3} / \mathrm{s}$, and $26.5 \mathrm{~m}^{3} / \mathrm{s}$, respectively. The flood hydrograph at the watershed outlet for the design storm with a 10-year return period is presented in Figure 5.

TABLE 4. Rainfall durations and intensities as the inputs to peak discharge simulations at every segment of the Belik Watershed.

\begin{tabular}{lccccc}
\hline \multirow{2}{*}{ Segment } & Duration (min) & \multicolumn{4}{c}{ Intensity (mm/min) } \\
\cline { 3 - 6 } & & 2-year & 5-year & 10-year & 25-year \\
\hline 1 & 41 & 0.93 & 1.31 & 1.87 & 1.87 \\
2 & 28 & 1.77 & 2.51 & 3.59 & 3.59 \\
3 & 68 & 0.40 & 0.57 & 0.82 & 0.82 \\
\hline
\end{tabular}




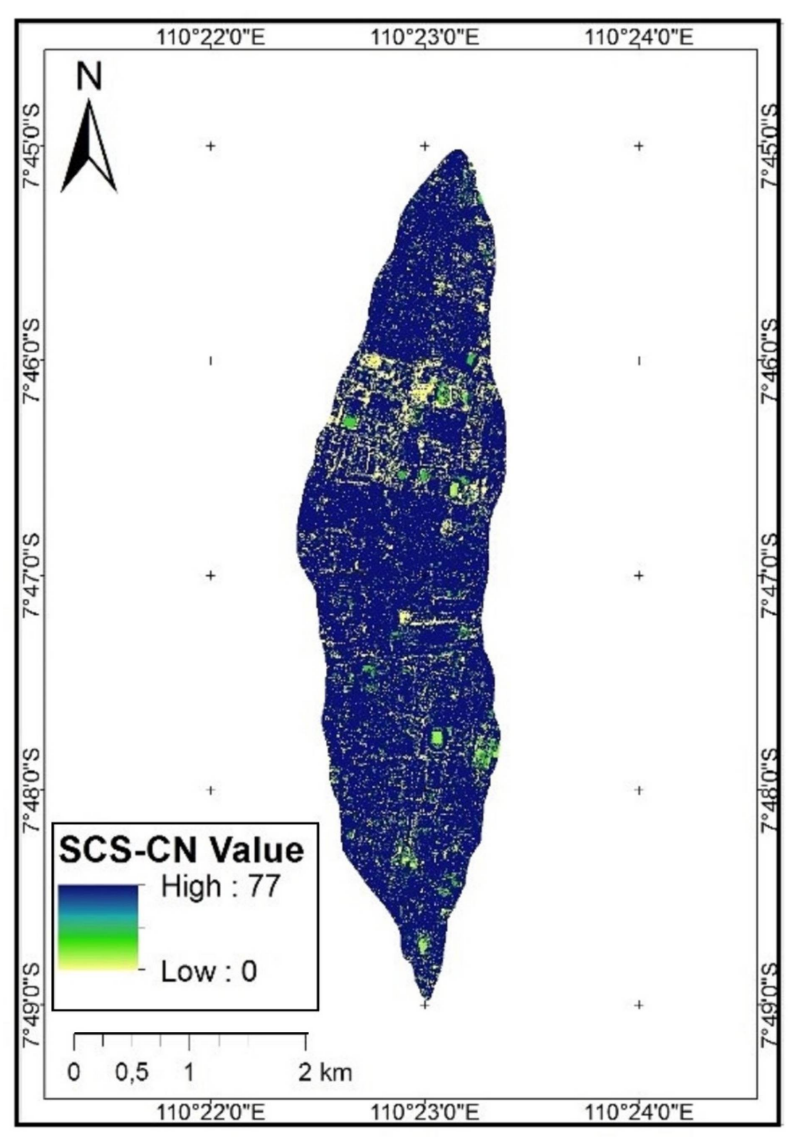

FIGURE 2. Curve numbers (CN) of the Belik Watershed.

\subsection{Peak discharge with 25-year return period}

Based on the 25-year design storm, the estimated peak discharge at the outlet of the watershed observed was 44.1 $\mathrm{m}^{3} / \mathrm{s}$. Segments 1,2 , and 3 yielded peak discharges of 8.9 $\mathrm{m}^{3} / \mathrm{s}, 21.5 \mathrm{~m}^{3} / \mathrm{s}$, and $36.58 \mathrm{~m}^{3} / \mathrm{s}$, respectively. The flood hydrograph at the watershed outlet for the design storm with a 25-year return period is shown in Figure 6.

Segment 2 was found to have a high rainfall intensity value as well as high $\mathrm{CN}$ value compared with the other segments. However, the highest peak discharge belonged to segment 3. Segment 3 contributed the most to the total peak discharge, which can be attributed to the high $\mathrm{CN}$

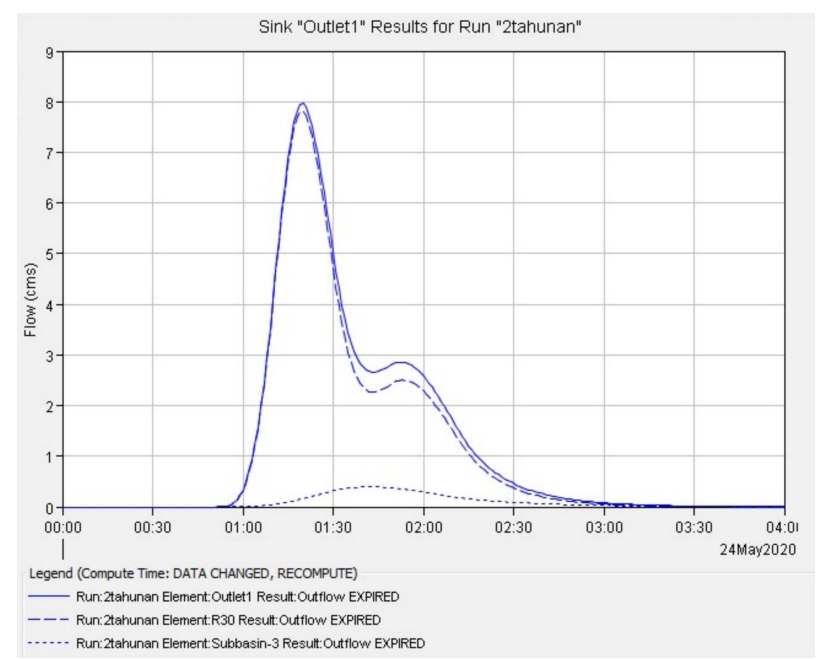

FIGURE 3. Flood hydrograph of the Belik Watershed based on 2-year peak discharge. value and rain volume identified in this segment. A high $\mathrm{CN}$ value means that less water is absorbed by the soil, and most portions of the rain landing on the surface transform into runoff. Accordingly, the solution to flood management issues at the studied watershed should involve structures that can capture more rainwater, including infiltration wells and drainage channels constructed with dimensions proportional to the catchment. The longer return period in the calculation of the peak discharge, the greater the peak discharge. The potential for peak discharge can be used as a long-term consideration when constructing waterways or building houses around rivers (floodplains). This consideration is made to reduce future losses.

Efforts to overcome urban floods are not only through structural development. If slowing the flow rate by constructing water structures is constrained, as a result of the lack of vacant land in urban areas, then non-structural mitigation is necessary. Non-structural research was carried out by (Shih et al. 2019), who found that the peak discharge from the modeling results cannot be accommodated by urban waterways, so efforts that can be made to reduce the risk of flooding include mapping the flood inundation areas and making a warning water level. This mitigation method can be applied to the Belik watershed, with modifications. However, this study can only provide peak discharge values, which means the mapping of inundation locations can be reexamined using other methods, one of which is HECRAS, to trace the water level along the water channel.

\section{CONCLUSIONS}

The peak storm discharges of the Belik Watershed for the return periods of $2,5,10$, and 25 years were $8.0 \mathrm{~m}^{3} / \mathrm{s}, 20.1$ $\mathrm{m}^{3} / \mathrm{s}, 29.9 \mathrm{~m}^{3} / \mathrm{s}$, and $44.1 \mathrm{~m}^{3} / \mathrm{s}$, respectively. The largest flow contribution to these discharges came from Segment 2 , which also had a high $\mathrm{CN}$ value. The simulation of peak discharge data can be used for flood management, an example of which is the evaluation of the capacity of urban drainage channels, so that when the river overflows it does not inundate housing. Furthermore, peak discharge data simulations can also be used in flood mitigation efforts. Flood control can include harvesting more rainwater by building structures such as infiltration wells or increasing the capacity of drainage channels.

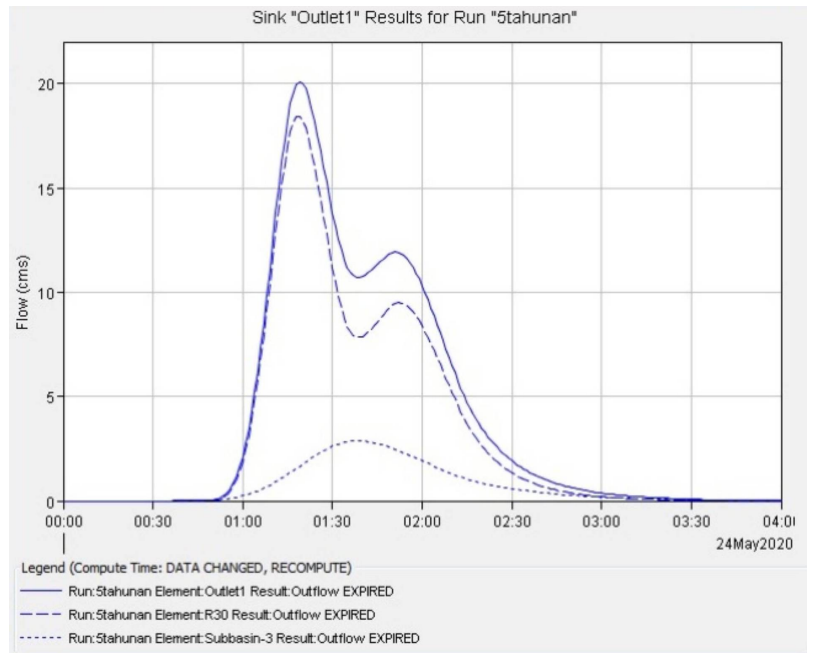

FIGURE 4. Flood hydrograph of the Belik Watershed based on 5-year peak discharge. 


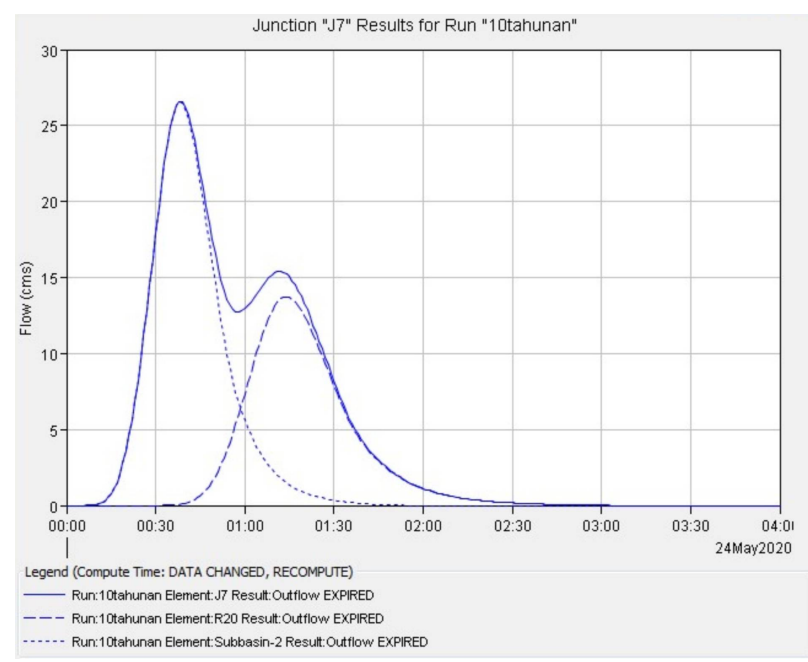

FIGURE 5. Flood hydrograph of the Belik Watershed based on 10-year peak discharge.

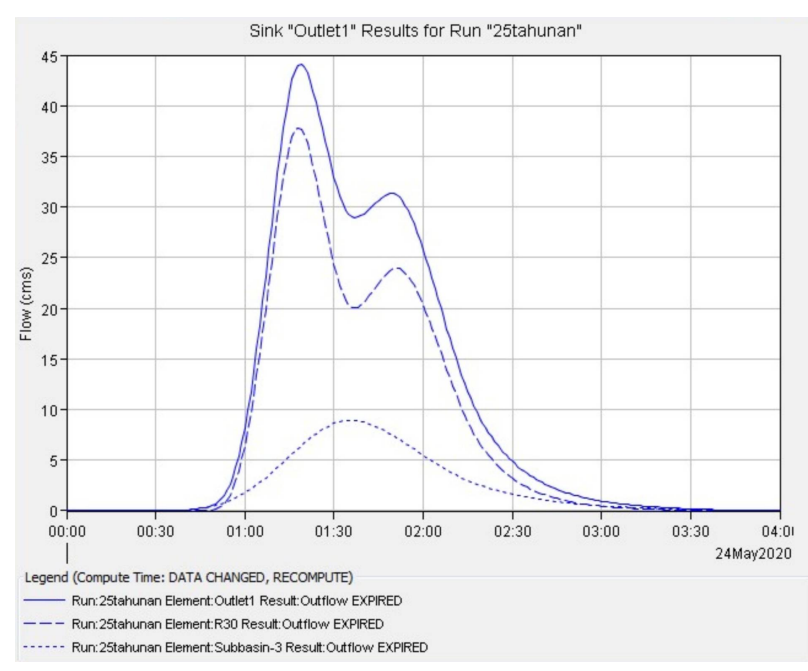

FIGURE 6. Flood hydrograph of the Belik Watershed based on 25-year peak discharge.

\section{ACKNOWLEDGMENTS}

This research was completed with the financial support of the Faculty of Geography, Universitas Gadjah Mada, Indonesia, through the independent research grant program. The authors would like to thank the faculty leadership for the opportunities given and support in this research.

\section{AUTHORS' CONTRIBUTIONS}

$\mathrm{SS}, \mathrm{R}$, and RL jointly coordinated and designed the research. $\mathrm{R}$ and RL collected data in preparation for field surveys. $\mathrm{R}$ conducted a field survey. Meanwhile, data analysis and manuscript writing were done together. All authors read and approved the final version of the manuscript.

\section{COMPETING INTERESTS}

The authors declare that they have no conflict of interest.

\section{REFERENCES}

Abushandi E, Merkel B. 2013. Modelling rainfall runoff relations using HEC-HMS and IHACRES for a single rain event in an arid region of Jordan. Water Resour Manage. 27(7):2391-2409. doi:10.1007/s11269-013-0293-4.
Bajwa H. 2002. Towards immersive virtual environments for GIS based hydrologic modeling [Master's thesis]. [Ames]: Iowa State University. doi:10.31274/rtd-202 00803-11.

Castro CV, Maidment DR. 2020. GIS preprocessing for rapid initialization of HEC-HMS hydrological basin models using web-based data services. Environ Model Softw. 130:104732. doi:10.1016/j.envsoft.2020.104732.

Halwatura D, Najim MMM. 2013. Application of the HECHMS model for runoff simulation in a tropical catchment. Environ Model Softw. 46:155-162. doi:10.1016/j. envsoft.2013.03.006.

Jamali B, Löwe R, Bach PM, Urich C, Arnbjerg-Nielsen K, Deletic A. 2018. A rapid urban flood inundation and damage assessment model. J Hydrol. 564:1085-1098. doi:10.1016/j.jhydrol.2018.07.064.

Majidi A, Shahedi K. 2012. Simulation of rainfall-runoff process using Green-Ampt method and HEC-HMS model (case study: Abnama watershed, Iran). Int J Hydraul Eng. 1(1):5-9.

Maria R, Lestiana H. 2014. Pengaruh penggunaan lahan terhadap fungsi konservasi air tanah di sub DAS Cikapundung [Effect of landuse on groundwater conservation function in Cikapundung sub-watershed]. Jurnal RISET Geologi dan Pertambangan. 24(2):77. doi:10.14203/ris etgeotam2014.v24.85.

Marko K, Zulkarnain F. 2018. Pemodelan debit banjir sehubungan dengan prediksi perubahan tutupan lahan di daerah aliran Cileungsi hulu menggunakan HEC-HMS [Modelling of flood discharge based on the prediction of land cover change in upper cileungsi catchment area using HEC-HMS]. Jurnal Geografi Lingkungan Tropik. 2(1). doi:10.7454/jglitrop.v2i1.31.

Nainggolan J, H YL, Sutikno S. 2015. Analisis dampak perubahan tata guna lahan DAS Siak bagian hulu terhadap debit banjir [The effect of land use change on the flood discharge in upper Siak watershed]. Jurnal Online Mahasiswa (JOM) Bidang Teknik dan Sains. 2(2):1-9. https: //jom.unri.ac.id/index.php/JOMFTEKNIK/article/vi ew/8010.

Oleyiblo JO, Li ZJ. 2010. Application of HEC-HMS for flood forecasting in Misai and Wan'an catchments in China. Water Sci Eng. 3(1):14-22. doi:10.3882/j.issn.1674-2370 .2010.01.002.

Prihatin RB. 2015. Alih fungsi lahan di perkotaan (studi kasus di kota Bandung dan Yogyakarta) [Land use changes in urban area (case study of Bandung and Yogyakarta city]. Aspirasi: Jurnal Masalah-masalah Sosial. 6(2):105118. doi:10.46807/aspirasi.v6i2.507.

Sarminingsih A, Rezagama A, Ridwan. 2019. Simulation of rainfall-runoff process using HEC-HMS model for Garang Watershed, Semarang, Indonesia. J Phys Conf Ser. 217(1):012134. doi:10.1088/1742-6596/1217/1/01213 4.

Shih SS, Kuo PH, Lai JS. 2019. A nonstructural flood prevention measure for mitigating urban inundation impacts along with river flooding effects. J Environ Manage. 251:109553. doi:10.1016/j.jenvman.2019.109553.

Suprayogi S, Latifah R, Marfai MA. 2020. Preliminary analysis of floods induced by urban development in Yogyakarta City, Indonesia. Geogr Tech. 15(2):57-71. doi: 10.21163/gt_2020.152.07.

Suprayogi S, Marfai MA, Cahyadi A, Latifah R, Fatchurohman H. 2019. Analyzing the characteristics of domestic wastes in Belik River, the Special 
Region of Yogyakarta, Indonesia. ASEAN J Sci Technol Dev. 36(3). doi:10.29037/ajstd.591.

Ud Din S, Muhammad NK, Israr M, Nabi H, Mansoorullah K. 2018. Runoff modelling using HEC HMS for Wural watershed. Int J Adv Eng Res Dev. 5(3):434-439.

[USACE] US Army Corps of Engineers Hydrologic Engineering Center. 2018. Hydrologic modeling system HECHMS user's manual version 4.3. Davis: US Army Corps of Engineers Hydrologic Engineering Center. https: //www.hec.usace.army.mil/software/hec-hms/do
cumentation/HEC-HMS_Users_Manual_4.3.pdf.

[USDA-SCS] US Department of Agriculture - Soil Conservation Service. 1986. TR-55: urban hydrology for small watersheds. https://www.nrcs.usda.gov/wps/portal /nrcs/detailfull/national/home/?cid=stelprdb10429 25.

Yusop Z, Chan CH, Katimon A. 2007. Runoff characteristics and application of HEC-HMS for modelling stormflow hydrograph in an oil palm catchment. Water Sci Technol. 56(8):41-48. doi:10.2166/wst.2007.690. 